\title{
Effects of Prenatal Perineal Massage and Kegel Exercises on the Integrity of Postnatal Perine*
}

\author{
Sevgul Dönmez ${ }^{1 \#}$, Oya Kavlak ${ }^{2}$ \\ ${ }^{1}$ Faculty of Health Sciences, Department of Gynecology and Obstetrics Nursing, Gaziantep University, \\ Gaziantep, Turkey \\ ${ }^{2}$ Faculty of Nursing, Department of Gynecology and Obstetrics Nursing, Ege University, İzmir, Turkey \\ Email: " $\underline{\text { donmezsevgul@gmail.com }}$
}

Received 29 March 2015; accepted 21 April 2015; published 27 April 2015

Copyright (C) 2015 by authors and Scientific Research Publishing Inc.

This work is licensed under the Creative Commons Attribution International License (CC BY). http://creativecommons.org/licenses/by/4.0/

(c) (i) Open Access

\begin{abstract}
Aim: This randomize controlled experimental study has been carried out to investigate the effects on the integrity of perine of perineal massage and Kegel exercises applied prenatally to women who experienced vaginal delivery. Methods: Research was carried out between January 2012 and 2013, with a total of 101 pregnant women who referred to Ege University Hospital in İzmir. Data Collection Form, Kegel Exercise Training Brochure, Practice Observation Form and Prenatal Perinea Massage Learning Guide for Implementer were used. Researcher continued to perform this massage once a week until delivery. Kegel exercises were asked to perform exercises at home and also to register them until delivery. When exercise group came to weekly controls or when they were contacted at home they were asked if they have performed daily exercise or not. The pregnant women in control group did not receive any application. One to one interview was performed during delivery and postnatal 24 hours at the hospital and a telephone interview was performed 15 days postnatal, so three groups were evaluated. The chi-square, Mann-Whitney $U$ test and Kruskal Wallis test were used. Results: A statistically significant difference was found between study and control groups in terms of episiotomy rates, laceration, postnatal 24 hours and 15 days perineal pain and improvement $(p<0.05)$. Conclusion: It was found that perineal massage and Kegel exercises are important in maintaining the integrity of perineal significantly. It is thought that when the perineal massage and Kegel exercise being performed during pregnancy is supported by health professional, it will play a significant role in women's quality of life.
\end{abstract}

\footnotetext{
*This trail was not registered in a standard webcite.

${ }^{\#}$ Corresponding author.
} 


\section{Keywords}

\section{Prenatal Care, Postnatal Care}

\section{Introduction}

Each year more than approximately 600,000 women die due to complications related to pregnancy and childbirth. Vast majority of them has been determined to occur in undeveloped countries. Antenatal, perinatal and postnatal care is among the fundamental protective services for protection and improvement of the health of both mother and the infant to be delivered [1].

To accomplish the childbirth safely with the least attempt possible for a healthy mother and infant is the objective of a qualified childbirth. Today, the fundamental approach related to pregnancy and childbirth is that childbirth is a physiological process and requires minimum level of medical intervention [2]. Childbirth and all the interventions performed during childbirth, with their dimensions and effects, are the great and important experiences that may lead to differences in the quality of life of the women and their families [3]-[6]. However, as a result of auspicious efforts and researches that will make normal childbirth safer and more qualified, a number of unnecessary interventions that are not appropriate, practiced inconveniently or do not help normal childbirth are being practiced [2]. These unnecessary interventions performed may cause perineal traumas that will accompany pre-and-post short and long term morbidity and may influence women's physical, psychological and social welfare [2] [6]-[10]. Besides, the perineal pain experienced as a result of birth lacerations may affect intra-family functions and daily life activities [3] [5] [6] [11]. Therefore, important changes have occurred in normal childbirth practices in last 30 years. Today, the place and the importance of many interventions that are performed during childbirth routinely are being questioned again in a manner based on evidence [5] [6] [12] [13].

The episiotomy that increases women's risks for being subjected to perineal trauma has become an intervention being used widespread today. Episiotomy is practiced during 50\% - 90\% of childbirths. In recent years the number of studies stating that episiotomy should be limited is increasing [3] [5] [12] [14]-[16].

For many years a number of studies have been carried out on techniques and practices that will alleviate these painful and troublesome situations during childbirth. Especially, the main objective of these studies has been to cause less bleeding during childbirth by reducing these episiotomy traumas and to facilitate mother's adjustment to new role by decreasing postnatal bleeding and the pain and grief at the perineal area [2] [4] [5] [7] [9] [12] [15]-[20].

In recent years, the investigations stating that antenatal perineal massage has positive effects on protecting the integrity of perineum and reducing the number and severity of lacerations are becoming widespread. Starting from 34th gestational week, perineal massage is practiced by the pregnant woman or her partner for 4 minutes 3 - 4 times a week or for 10 minutes once a week which suggests performing a antenatal perineal massage by the woman or her partner before delivery. Performing a antenatal perineal massage by the woman or her partner a few weeks prior to the delivery has been advocated to increase elasticity and reduce the risk of perineal trauma from episiotomy or spontaneous tears [4] [7] [10] [14] [21] [22].

On the other hand, Dr. Arnold Kegel in 1940 discovered the squeeze and hold vaginal exercises known as Kegel's were specifically designed to target pelvic floor strengthening. Moreover, it is suggested that, since damage due to vaginal delivery occur in supportive pelvic issues and in the nervous structures related to them, the Kegel exercises reduce the laceration rate occurring during vaginal delivery, give vaginal and perineal muscles their previous tones, decrease the edema in perineal region, accelerate the circulation and prevent the stretch of abdominal muscles thereby prolapse and backache, as well as preventing the known stress incontinence [11] [23]-[28].

\section{Aim}

The aim of this research which was carried out with women making vaginal delivery was to investigate the effects of perinal massage and the Kegel exercises practiced before childbirth on episiotomy rate by reducing perineal trauma during delivery and on the postnatal perineal pain and its improvement. 


\section{Materials and Methods}

\subsection{Study Design and Sample}

This randomize controlled experimental research was carried out with 101 pregnant women (30 massages, 32 exercises and 39 controls) who completed 33 gestation weeks and referred to pregnancy polyclinic of Department of Maternity and Gynecology, Ege University between 1 January 2012 and 1 January 2013 (Figure 1).

Inclusion criteria were to be between 18 and 35 years of age, to be at least elementary graduate, willing to participate into study, to deliver first infant, not to have risky pregnancy, not to have any known cesarean indication, willing to make normal delivery and to come to hospital at least once a week and not to be annoyed by their genital areas touched or oil applied.

In arrangement of study groups a systematic randomization method was used. The pregnancy polyclinic has been visited five days a week to select these pregnant women. Pregnant women between 18 and 35 years of age and experiencing their first or second pregnancy were interviewed. Pregnant women were told to be followed up until delivery. As long as they were willing to participate into study, they were randomized into massage, exercise and control groups based on the day they referred to polyclinic. The massage, exercise and control groups were selected at the first, second and third days of the week respectively. Randomization of pregnant women into massage, exercise and control groups was continued at other workdays. The massage group was selected at massage day, exercise group at exercise day and control group at control day; so, selection of other groups was not performed during one group's selection day. All the pregnant women who volunteered to participate into

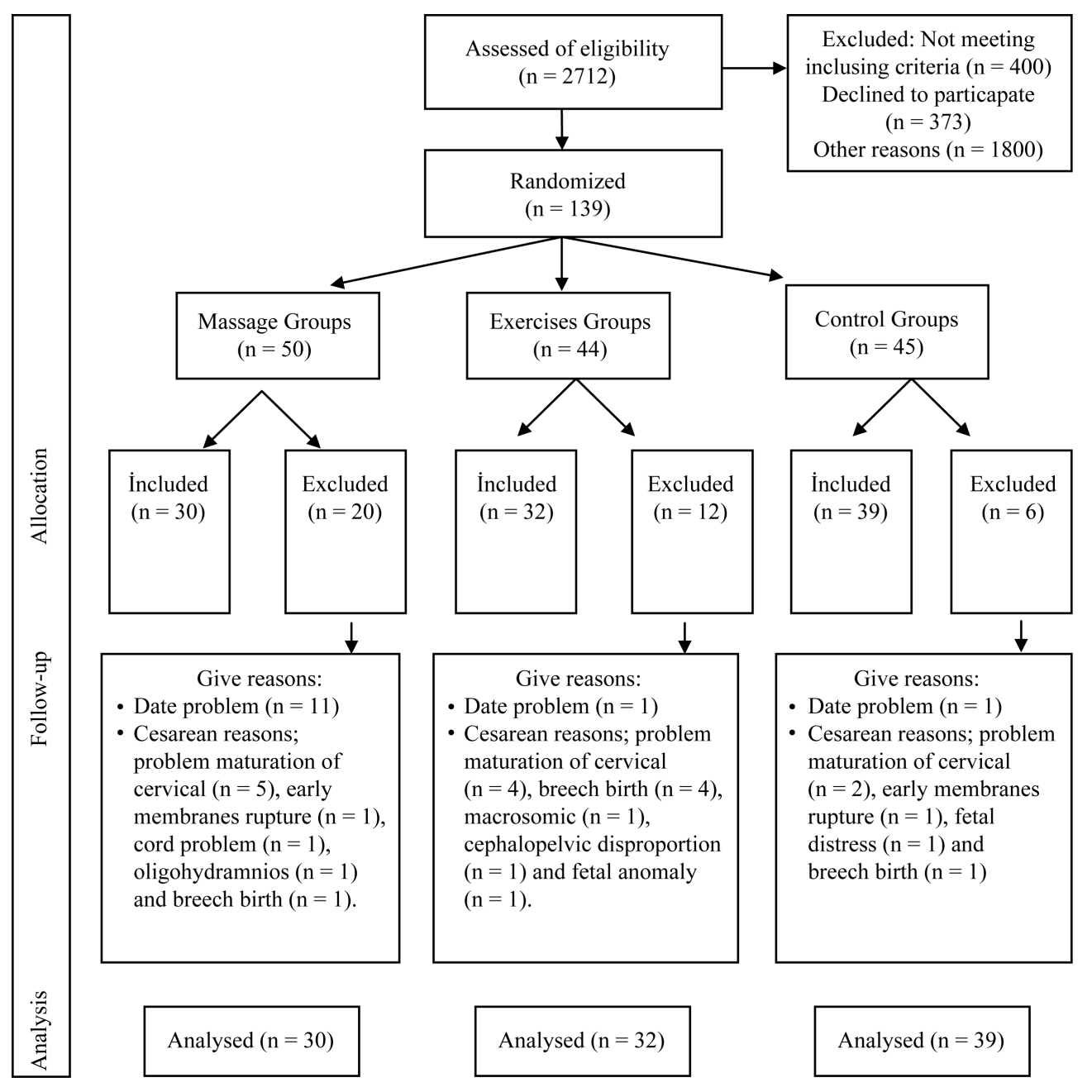

Figure 1. The study flow chart. 
the study filled out an informed consent form. The pregnant women participated into study were not aware of the group they were selected for, therefore they had no idea about the method applied. However, researchers knew the volunteers selected for trial and control groups, as well as what methods were applied to them.

After the groups were formed, information related to the importance of the massage was given to massage group by the researcher and pregnant women were told to empty their bladders. The pregnant woman was laid down in the lithotomy position in a bed located in the designated empty room. Massage was performed by inserting 1 or 2 fingers 3 to $5 \mathrm{~cm}$ into the vagina and sweeping downward and from side to side, using almond oil for lubrication. According to Antenatal Perineal Massage Learning Guide massage with cacao oil was applied to perineal area by researcher for ten minutes [2] [9] [22] [29] [30].

Kegel exercises were taught to exercise group so that they can use base pelvic muscles and they performed this exercise once next to researcher. In order to teach exercise, they were told to contract the muscles in the base of pelvis by inserting two fingers into vagina and to try to constrict vagina. During this contraction time, woman was made aware of her muscles. Pregnant woman was told to continue contracting it for about 3 seconds and then to loosening it for 3 seconds. Subjects were asked to perform this exercise at home at least 5 - 10 times until childbirth. Besides, the training brochure and the application observation form developed by researcher were handed out to pregnant women. Women were asked to register the exercises performed daily on the application observation form with the duration and frequency. The women in exercise group were checked out whether they have performed exercises when they came to control each week or through telephone calls.

Perineal massage, Kegel exercise or any other intervention was not applied to the pregnant women in control group. In order to determine the postnatal effects of the massage and exercise, three groups of data collection form were used and evaluated through interview performed one by one in the hospital during childbirth, 24 hours after delivery and through phone interview made 15 days after delivery.

\subsection{Data Collection}

In collection of research data, Written Consent Form, Data Collection Form, REEDA Scale, Kegel Exercise Training Brochure and Application Follow-up Form, Antenatal Perineal Massage Learning Guide for practicer and Cacao Oil were used.

\subsection{The Data Collection Form}

The data collection form developed by researcher consistent with literature (in which certain peri- and postnatal variables were questioned) consisted of 40 questions involving pregnant women's sociodemographic features such as age and education. In addition, a REEDA Scale took place in the data collection form.

REEDA Scale was developed by Davidson in 1979 to reach objective results in postnatal assessment of perineum. The validity and reliability study of the scale was completed by Hill in 1989. Its validity and reliability study in our country was performed by Üstünsöz (1996). Scale is comprised of 5 parameters of wound healing as described below.

- Redness;

- Edema;

- Ecchymosis;

- Discharge;

- Approximation.

Scale is evaluated by giving $0,1,2$ and 3 score to each assessment. The lowest score is 0 and the highest score is 15 . The highest score indicates the most serious perineal trauma.

\subsection{The Kegel Exercise Training Brochure and Application Follow-Up Form}

The training brochure developed by researcher consistent with literature for the pregnant women in exercise group consisted of a brochure describing them how to perform Kegel exercise and an application follow-up table where they can register their exercises.

\subsection{Ethical Considerations}

For research necessary permission was obtained from Local Ethical Committee of Ege University Hospital. In 
order to use it in the data collection form of Üstünsöz’s (1996) written approval who performed the Turkish Validity and Reliability of REEDA Scale was obtained. Objective of the study was explained to the women included in research by researcher and their written contents for participation were obtained.

\subsection{Data Analysis and Sample Size}

Analysis of the data obtained from research was performed with SPSS 15.0 package program. While the data of study were evaluated the frequency, percentage, number, average, standard deviation and minimum-maximum were used. For homogeneity test between study and control groups, during comparison made between demographic variables and other qualitative and quantitative data, the Chi-square, Fisher Exact Test, Mann-Whitney U Test and Kruskal Wallis Test were used. In addition, a power analysis was performed to determine the number of sample and to demonstrate the strength of the research. Results were evaluated at $95 \%$ confidence interval and at $\mathrm{p}<0.05$ significance level.

To determine the sample that would constitute necessary massage, exercise and control groups for research, first a pilot study was carried out with a total of 30 volunteers (10 from each group); subsequently, necessary sampling count was determined as 96 pregnant women by performing power analysis based on this pilot study.

\section{Findings}

Any statistically significant difference could not be found between study and control groups in terms of mean age, occupation and education ( $\mathrm{p}=0.125)$ (Table 1$)$. The mean gestation weeks of pregnant women in massage, exercise and control groups were $39.16 \pm 1.05$, $39.18 \pm 1.33$ and $38.66 \pm 2.14$ respectively; whereas any statistically significant difference was not found between them $(\mathrm{p}=0.940)$. When pregnant women's distribution according to intervention application status was examined, any statistically significant difference could not be found between massage, exercise and control groups of pregnant women in terms of epidural anesthesia $(p=0.437)$, crede maneuver $(\mathrm{p}=0.254)$, forceps/vacuum $(\mathrm{p}=1.000)$ and induction application status $(\mathrm{p}=0.119)$ (Table 2).

Although any statistically significant difference was not found between infants' weight $(\mathrm{p}=0.054)$, mean 1

Table 1. Demographic and sociodemographic characteristics and variables concerning the period before and during pregnancy $(\mathrm{n}=101)$.

\begin{tabular}{|c|c|c|c|c|c|}
\hline & $\begin{array}{l}\text { Massage Groups } \\
\qquad(\mathrm{n}=30)\end{array}$ & $\begin{array}{l}\text { Exercise Groups } \\
\qquad(\mathrm{n}=32)\end{array}$ & $\begin{array}{l}\text { Control Groups } \\
\qquad(\mathrm{n}=39)\end{array}$ & KW & $\mathrm{p}$ \\
\hline \multicolumn{6}{|c|}{ Sociodemographic charateristics } \\
\hline Age (year), mean \pm SD & $26.90 \pm 4.64$ & $28.03 \pm 4.15$ & $24.25 \pm 4.15$ & 39.335 & 0.243 \\
\hline $\begin{array}{l}\text { Primary/secondary school } \\
\text { graduates (8 years), n (\%) }\end{array}$ & $6(20.0)$ & $12(37.5)$ & $16(41.0)$ & \multirow[b]{2}{*}{$X^{2}=4.154$} & \multirow[b]{2}{*}{0.125} \\
\hline $\begin{array}{l}\text { High school/university graduates, } \\
\text { n (\%) }\end{array}$ & $24(80.0)$ & $20(62.5)$ & $23(59.0)$ & & \\
\hline $\begin{array}{l}\text { Profession, n (\%) } \\
\text { Unemployed } \\
\text { Official } \\
\text { Unofficial sector }\end{array}$ & $\begin{array}{l}19(63.3) \\
9(30.0) \\
2(6.7)\end{array}$ & $\begin{array}{c}27(84.4) \\
4(12.5) \\
1(3.1)\end{array}$ & $\begin{array}{l}27(69.2) \\
9(23.1) \\
3(7.7)\end{array}$ & Fisher ex & $=0.411$ \\
\hline \multicolumn{4}{|c|}{ Variables concerning the period pregnancy } & $\mathrm{X}^{2}$ & $\mathrm{p}$ \\
\hline Gravidity <2, n (\%) & 25 (83.3) & $16(50.0)$ & $28(71.8)$ & 8.221 & $0.016^{*}$ \\
\hline Number of Live Birth, n (\%) & $4(13.3)$ & $15(46.9)$ & $8(20.5)$ & \multicolumn{2}{|c|}{ Fisher exact test $\mathrm{p}=0.008^{*}$} \\
\hline Abortion, n (\%) & $1(3.3)$ & $1(3.1)$ & $3(7.7)$ & \multicolumn{2}{|c|}{ Fisher exact test $\mathrm{p}=1.000$} \\
\hline \multicolumn{6}{|l|}{ Frequent of prenatal care, n (\%) } \\
\hline $\begin{array}{l}4-6 \text { times } \\
7 \text { - } 9 \text { times } \\
10 \text { and above }\end{array}$ & $\begin{array}{c}3(10.0) \\
3(10.0) \\
24(80.0)\end{array}$ & $\begin{array}{c}3(9.4) \\
10(31.3) \\
19(59.3)\end{array}$ & $\begin{array}{c}1(2.6) \\
13(33.3) \\
25(64.1)\end{array}$ & \multicolumn{2}{|c|}{ Fisher exact test $\mathrm{p}=0.092$} \\
\hline
\end{tabular}

${ }^{*} \mathrm{p}<0.05$. 
Table 2. Variables concerning labor and newborns $(\mathrm{n}=101)$.

\begin{tabular}{|c|c|c|c|c|c|}
\hline & $\begin{array}{l}\text { Massage Groups } \\
\quad(\mathrm{n}=30)\end{array}$ & $\begin{array}{l}\text { Exercise Groups } \\
\quad(\mathrm{n}=32)\end{array}$ & $\begin{array}{l}\text { Control Groups } \\
\qquad(\mathrm{n}=39)\end{array}$ & KW & $\mathrm{p}$ \\
\hline \multicolumn{6}{|c|}{ Labor } \\
\hline Gestation week, mean \pm SD & $39.16 \pm 1.05$ & $39.18 \pm 1.33$ & $38.66 \pm 2.14$ & 1.123 & 0.940 \\
\hline \multicolumn{6}{|l|}{ Reasons of coming birth $\mathrm{n}(\%)$} \\
\hline Coming of amniotic liquid & $10(33.3)$ & $11(34.4)$ & $12(30.8)$ & \multirow{4}{*}{\multicolumn{2}{|c|}{ Fisher exact test $\mathrm{p}=0.888$}} \\
\hline Pain & $15(50.0)$ & $14(43.8)$ & $18(46.2)$ & & \\
\hline Coming of birth sign & $1(3.3)$ & $2(6.3)$ & $5(12.8)$ & & \\
\hline Over birth weeks & $4(13.4)$ & $5(15.5)$ & $4(10.2)$ & & \\
\hline Application of epidural anesthesia, $n$ (\%) & $1(3.3)$ & $1(3.1)$ & $4(10.3)$ & \multicolumn{2}{|c|}{ Fisher exact test $\mathrm{p}=0.437$} \\
\hline Application of crede maneuver, $\mathrm{n}(\%)$ & $8(26.7)$ & $12(37.5)$ & $18(46.2)$ & $X^{2}=2.744$ & 0.254 \\
\hline Application of forceps/vacuum, n (\%) & $0(0.0)$ & $1(3.1)$ & $1(2.6)$ & \multicolumn{2}{|c|}{ Fisher exact test $\mathrm{p}=1.000$} \\
\hline Application of induction, $\mathrm{n}(\%)$ & $9(30.0)$ & $16(50.0)$ & $21(53.8)$ & $X^{2}=4.263$ & 0.119 \\
\hline $\begin{array}{l}\text { Duration of applicated induction } \\
\text { (hour), mean } \pm \text { SD }\end{array}$ & $6.44 \pm 2.50$ & $5.62 \pm 2.41$ & $4.33 \pm 3.56$ & $\mathrm{KW}=2.038$ & 0.361 \\
\hline $\begin{array}{l}\text { Mean duration of the second stage (min), } \\
\text { mean } \pm \text { SD }\end{array}$ & $285.66 \pm 169.05$ & $293.90 \pm 255.00$ & $232.43 \pm 198.63$ & $\mathrm{KW}=4.606$ & 0.100 \\
\hline \multicolumn{6}{|l|}{ Difficulty of the birth, n (\%) } \\
\hline Mild & $25(83.4)$ & 13 (40.6) & $5(12.8)$ & \multirow{3}{*}{\multicolumn{2}{|c|}{ Fisher exact test $\mathrm{p}=0.000^{*}$}} \\
\hline Severe & $4(13.3)$ & 15 (46.9) & $16(41.0)$ & & \\
\hline \multirow[t]{2}{*}{ Unbearable } & $1(3.3)$ & $4(12.5)$ & $18(46.2)$ & & \\
\hline & Newborn & & & KW & $\mathrm{p}$ \\
\hline Weight (kg), mean \pm SD & $3038 \pm 300.24$ & $3213.43 \pm 430.84$ & $3175.25 \pm 583.37$ & 5.838 & 0.054 \\
\hline Head circumference $(\mathrm{cm})$, mean \pm SD & $31.63 \pm 1.49$ & $31.46 \pm 1.70$ & $33.07 \pm 1.34$ & 24.350 & $0.000^{*}$ \\
\hline 1. minute Apgar score, mean \pm SD & $7.90 \pm 1.15$ & $7.59 \pm 1.18$ & $7.48 \pm 2.15$ & 1.648 & 0.439 \\
\hline 5. minute Apgar score, mean \pm SD & $9.23 \pm 0.97$ & $9.12 \pm 0.97$ & $8.79 \pm 1.96$ & 0.151 & 0.927 \\
\hline
\end{tabular}

${ }^{*} \mathrm{p}<0.05$.

minute Apgar scores $(p=0.439)$ and 5-minute Apgar scores $(p=0.927)$ when the antenatal follow-up features of infants of pregnant women in study and control groups were examined, however, a statistically significant difference was found in terms of infants' mean head circumferences $(p=0.000)$ (Table 2).

It was found that episiotomy was applied to $83.3 \%, 87.5 \%$ and $100 \%$ of pregnant women in massage, exercise and control groups and a statistically difference was found $(\mathrm{p}=0.014)$. Laceration occurred in $16.7 \%, 56.3 \%$ and $82.1 \%$ of pregnant women in massage, exercise and control groups but any statistically significant difference could not be found. It was determined that a package was used for perineal trauma in $73.3 \%$ of pregnant women in massage group, two packages in $43.8 \%$ of pregnant women in massage group and three and more suture materials in 56.4 of the pregnant women in control group but any statistically significant difference could not be found $(\mathrm{p}=0.000)$ (Table 3$)$.

A statistically significant difference was found between pregnant women in massage and control groups in terms of perineal pain and wound healing 24 hours $(p=0.000 ; p=0.000)$ and 15 days after childbirth $(p=0.000$; $\mathrm{p}=0.000)$ (REEDA Scale) (Table 4).

\section{Discussion}

This study is a randomized controlled research comprised of pregnant women in the first and second gestation. Throughout the study period pregnant women were followed-up beginning from the 33th gestational week until 24 hours and 15 days after childbirth and data were collected 24 hours and 15 days after childbirth. 
Table 3. Comparison of perineal outcomes between the massage and control groups $(n=101)$.

\begin{tabular}{|c|c|c|c|c|c|}
\hline Perineal Outcomes & $\begin{array}{l}\text { Massage Groups } \\
\qquad(\mathrm{n}=30)\end{array}$ & $\begin{array}{l}\text { Exercise Groups } \\
\qquad(\mathrm{n}=32)\end{array}$ & $\begin{array}{l}\text { Control Groups } \\
\qquad(\mathrm{n}=39)\end{array}$ & \multicolumn{2}{|c|}{ Fisher Exact Test p } \\
\hline Episiotomy, n (\%) & $25(83.3)$ & $28(87.5)$ & 39 (100) & \multicolumn{2}{|c|}{$0.014^{*}$} \\
\hline Laceration, n (\%) & $5(16.7)$ & $18(56.3)$ & $32(82.1)$ & $X^{2}=29.290$ & $0.000^{*}$ \\
\hline \multicolumn{6}{|l|}{ Degree of Laceration, n (\%) } \\
\hline None & 25 (83.3) & $14(43.8)$ & $7(17.9)$ & \multirow{5}{*}{\multicolumn{2}{|c|}{ Fisher exact test $\mathrm{p}=0.000$}} \\
\hline 1 degree & $2(6.7)$ & $11(34.4)$ & $5(12.8)$ & & \\
\hline 2 degree & $1(3.3)$ & $5(15.6)$ & $15(38.5)$ & & \\
\hline 3 degree & $2(6.7)$ & $2(6.2)$ & 10 (25.7) & & \\
\hline 4 degree & $0(0.0)$ & $0(0.0)$ & $2(5.1)$ & & \\
\hline \multicolumn{6}{|c|}{$\begin{array}{l}\text { Mean number of packs of suture } \\
\text { material }(90 \mathrm{~cm}), \mathrm{n}(\%)\end{array}$} \\
\hline None & $3(10.0)$ & $2(6.3)$ & $0(0.0)$ & \multirow{4}{*}{$X^{2}=48.763$} & \multirow{4}{*}{$0.000^{*}$} \\
\hline 1 pack & 22 (73.3) & $11(34.3)$ & $3(7.7)$ & & \\
\hline 2 packs & $2(6.7)$ & $14(43.8)$ & 14 (35.9) & & \\
\hline 3 packs and above & $3(10.0)$ & $5(15.6)$ & $22(56.4)$ & & \\
\hline
\end{tabular}

Table 4. Perineal outcomes twenty-four hours and fifteen days after delivery $(n=101)$.

\begin{tabular}{|c|c|c|c|c|c|}
\hline & $\begin{array}{l}\text { Massage Groups } \\
\quad(\mathrm{n}=30)\end{array}$ & $\begin{array}{l}\text { Exercise Groups } \\
\qquad(\mathrm{n}=32)\end{array}$ & $\begin{array}{l}\text { Control Groups } \\
\qquad(\mathrm{n}=39)\end{array}$ & KW & $\mathrm{p}$ \\
\hline Perineal pain after 24 hours, mean \pm SD & $3.33 \pm 2.17$ & $4.59 \pm 2.58$ & $5.89 \pm 2.64$ & 15.36 & $0.000^{*}$ \\
\hline Perineal pain after 15 days, mean \pm SD & $0.63 \pm 1.27$ & $1.87 \pm 1.87$ & $3.17 \pm 2.59$ & 22.875 & $0.000^{*}$ \\
\hline $\begin{array}{l}\text { The wound healing of after } 24 \text { hours } \\
\text { (REEDA Scale), mean } \pm \text { SD }\end{array}$ & $4.70 \pm 1.64$ & $5.59 \pm 2.09$ & $7.41 \pm 2.44$ & 23.692 & $0.000^{*}$ \\
\hline $\begin{array}{l}\text { The wound healing of after } 15 \text { days } \\
\text { (REEDA Scale), mean } \pm \text { SD }\end{array}$ & $1.83 \pm 1.17$ & $2.25 \pm 1.45$ & $3.30 \pm 1.70$ & 15.76 & $0.000^{*}$ \\
\hline
\end{tabular}

Pregnancy and childbirth are among the primary factors leading to trauma at the pelvic floor. In fact, many interventions that need not to be done during vaginal delivery have become practically implemented [2]. These unnecessary interventions may cause perineal traumas that are seen widespread and affect health of women negatively [2] [6]-[10] [21] [31]. In this study most of the interventions which were risk factors for perineal trauma were applied.

Approximately $20 \%$ and $30 \%$ of all pregnant women are induced during delivery and birth induction has become the frequently applied medical intervention [32]. In this study the birth induction is used less in massage group, however, it is utilized in exercise and control groups at similar rates. In a study by Eogan et al. (2006) while childbirth started spontaneously in massage group, the rate of need for induction was found higher in the group not performing massage [29]. Another study found the birth rate starting spontaneously higher in control group [33]. In a study by Karaçam et al. (2012) the induction usage rate in the group that received antenatal massage was found as $97.5 \%$, it was $94.9 \%$ in control group. The difference between two groups was found statistically significant [5]. In another study the induction usage rate in the group that received antenatal massage was found as $73 \%$, it was $67 \%$ in control group. The difference between two groups was found statistically significant [4].

In this study, a statistically difference could not be found in the second period of childbirth in terms of mean lengths. In another study, similar to this study, a statistically difference could not be found between the groups perineal massage was practiced and not practiced in terms of length of birth event [29]. Salvesen and Morkved (2004) were evaluated the effects of pelvic floor muscle exercise during pregnancy on the childbirth and different from our study, found prolongation of the second phase of delivery less in exercise group [34]. In two studies where pelvic floor muscle exercises were scrutinized, a statistically significant difference could not be 
found between exercise and control groups in terms of length of the second phase of childbirth [11] [24].

In our study it was found that the episiotomy application rate to massage and exercise groups was less compared to control group $(p=0.014)$. In the studies whether any relationship between antenatal perineal application rate and use of episiotomy was investigated. While some studies determined a relationship [2] [5] [22] [35] others stated that antenatal perineal massage application had a minor effect in reducing the episiotomy application [10] [33] [36].

In our study the laceration formation rate during childbirth was determined less in massage and exercise groups than in control group $(p=0.000)$. Recently, research suggesting that the antenatal preneal massage had positive effects on protection of the integrity of perineum and reduction of the number and severity of lacerations, becomes widespread [4] [14] [18] [21] [22]. When the data base of Cochrane Pregnancy and Childbirth was examined it was observed that antenatal preneal massage had reduced the perineal trauma as well as the need for episiotomy and the perineal pain [21]. In a study carried out in UK, the effect of perineal massage performed antenatally was evaluated in 861 nulliparous women and perineal damage was found statistically significant in terms of benefit. In a Canadian study (1999) 1034 participants were evaluated and a statistically significant increase was established in study group in terms of protection of the integrity of perineum [9]. In a study performed by Bolandhemmat et al. (2001), the incidence of perineal lecaration was found as $9.7 \%$ in perineal massage group and as $45.2 \%$ in control group [31]. In a study by Avery and Burket (1986) the rate of laceration in perineum was found less in antenatal preneal massage group [37]. There were other studies that discovered a decrease in perineal laceration incidence in women for whom perineal massage was applied compared to those not applied [29] [37] [38]. In two studies any statistically significant difference could not be found between the group which received perineal massage and the one not received [5] [20].

In a study where antenatal Kegel exercises were scrutinized, any statistically significant difference could not be found in terms of decrease of laceration incidence by Kegel exercise [11]. In a randomized study where the effects of pelvic floor exercises performed during pregnancy on childbirth and newborn outcomes were examined, any statistically significant difference could not be found between exercise and control groups in terms of laceration incidence [24]. Johansan (2000) stated that pelvic floor muscle exercises performed from the 35th week of gestation until childbirth was effective in decreasing the laceration, was able to increase the elasticity of perineum and to reduce the perineal trauma [7]. Furthermore, other studies suggest that it reduces possibility of laceration in vaginal deliveries since it increases perineum's tone and elasticity [25] [39]. Further studies that will examine the effects of pelvic floor muscle exercises on the integrity of perineum are needed.

In our study laceration degree was found less in massage and exercise groups than in control group $(\mathrm{p}=$ 0.000). In some studies although the first and second degree laceration rates were found almost similar in massaging and not massaging groups, however, the third and fourth degree laceration rates were higher in control group [10] [33]. In another study, the first degree laceration rate was found lower in massaging group, whereas the second degree laceration rate was higher in massaging group [9]. However, in two studies performed the first degree laceration rate was found higher in massage group [4] [5].

In our study the amount of suture material used for perineal trauma was found less in massage and exercise groups than in control group $(\mathrm{p}=0.000)$. A study with larger sampling reported that vast majority of women who made vaginal delivery were somehow subjected to perineal trauma and 2/3 of them required suture [7]. In another study any statistically significant difference could not be found between massage and control groups in terms of amount of suture material used in perineal trauma [9]; however, in another study this difference was found statistically significant [5].

In our study, antenatal massages and exercises were found to reduce perineal pain experienced 24 hours and 15 days after childbirth. Some studies discovered that perineal massage had reduced the perineal pain in postnatal period [22] [29] [35]. In a study by Labrecque et al. (2000) a difference could not be found between groups massaging and not massaging in terms of perineal pain [40]. Another study reported that $40 \%$ of women were still experiencing perineal pain in postnatal first two weeks, $20 \%$ in 8th week and 9\% in 3rd week [41].

In our study the massages and exercised performed antenatally were found to accelerate healing of wound after 24 hours and 15 days after delivery (Reeda Scale). In another study the difference between groups that received massage and not received was not found statistically significance in terms of healing of perineal wound 24 hours and three weeks after childbirth [5]. Other studies stated that since pelvic floor muscle exercises performed from 35th week of gestation until childbirth would increase the tone and elasticity of perineum, they could reduce the possibility of laceration in vaginal deliveries, so healing of episiotomy wound would be faster 
in exercising women [25] [39]. In multiparous women who referred to deliver their second babies, the healing time of episiotomy in their previous childbirth was determined as $10.40 \pm 2.67$ days [2]. In a research by Üstünsöz (1996), the healing time of previous episiotomy in multiparous women included into research was found to be $45 \%$ in 14 days and over and 39.5\% in 10 - 13 days. According to a systematic compilation made in randomized controlled studies, the exercises that strengthened pelvic floor muscles during gestation had proven to protect integrity of perineum within a period varying between postnatal six weeks and three months [26].

\section{Conclusion}

A statistically significant difference was found between study and control groups in terms of episiotomy application status, laceration formation status, laceration degree, perineal pain 24 hours and 15 days after delivery and mean scores of REEDA Scale. According to the results of research, antenatal perineal massage and Kegel exercise reduce the use of episiotomy and significantly affect the perineal trauma and postnatal perineal pain and healing. In line with these findings, the prenatal perineal massage and Kegel exercise decrease perineal lacerations and episiotomy rate in the postnatal period, thereby accelerate healing during postnatal period. Perineal massage and Kegel exercise practiced during gestation should be supported by health professional for they may play an important role in improving the quality of life of women in both prenatal and postnatal periods.

\section{Limitations and Difficulties Encountered}

Subjects are experiencing difficulties with the rendezvous because routine episiotomy is applied to primiparous women in the hospital where the study is carried out, because randomized controlled studies that investigate the prenatal and postnatal effects of antenatal perineal massage and Kegel exercise are sparse, because there are differences in knowledge and skills of health professional performing childbirth and because every childbirth cannot be performed by the same professional since the hospital where research is carried out is a training hospital and because duration of research is longer.

\section{Acknowledgements}

This work was supported by Ege Universtity Hospital and funded by the State Planning Organization, Turkey.

\section{Disclosure}

The authors have no conflicts of interest to disclose.

\section{Author Contribution}

S. Dönmez: Protocol/project development, data collection, data analysis, manuscript writing.

O. Kavlak: Protocol/project development, data analysis, manuscript editing.

\section{References}

[1] Sönmez, Y. (2007) Doğum öncesi bakım hizmetleri (The Prenatal Care Services). Sürekli Tip Eğitimi Dergisi, 16, 9-12 (in Turkish).

[2] Sayıner, F.D. and Demirci, N. (2007) Prenatal perineal masajın vaginal doğumlarda etkinliği (Effectiveness of Prenatal Perineal Massage in Vaginal Delivery). Florence Nightingale Hemşirelik Dergisi, 15, 146-154 (in Turkish).

[3] Albers, L.L. and Borders, N. (2007) Minimizing Genital Tract Trauma and Related Pain Following Spontaneous Vaginal Birth. Journal of Midwifery \& Women's Health, 52, 246-253.

[4] Geranmayeh, M., Habibabadi, Z.R., Fallahkish, B., Mahdi Azizabadi Farahani, M.A., Zohreh Khakbazan, Z. And Abbas Mehran, A. (2012) Reducing Perineal Trauma through Perineal Massage with Vaseline in Second Stage of Labor. Archives of Gynecology and Obstetrics, 285, 77-81. http://dx.doi.org/10.1007/s00404-011-1919-5

[5] Karaçam, Z., Ekmen, E. and Çalışır, H. (2012) The Use of Perineal Massage in the Second Stage of Labor and FollowUp of Postpartum Perineal Outcomes. Health Care For Women International, 33, 697-718. http://dx.doi.org/10.1080/07399332.2012.655385

[6] Manzanares, S., Cobo, D., Moreno-Martínez, M.D., Sánchez-Gila, M. and Pineda, A. (2013) Risk of Episiotomy and Perineal Lacerations Recurring after First Delivery. Birth, 40, 307-311. http://dx.doi.org/10.1111/birt.12077 
[7] Johanson, R. (2000) Perineal Massage for Prevention of Perineal Trauma in Childbirth. The Lancet, 355, $250-251$. http://dx.doi.org/10.1016/S0140-6736(00)00020-9

[8] Karaçam, Z. and Eroğlu, K. (2003) Effects of Episiotomy on Bonding and Mother's Health. Journal of Advanced Nursing, 43, 384-394. http://dx.doi.org/10.1046/j.1365-2648.2003.02727.x

[9] Mei-dan, E., Walfisch, A., Raz, I., Levy, A. and Hallak, M. (2008) Perineal Massage during Pregnancy: A Prospective Controlled Trial. The Israel Medical Association Journal (IMAJ), 10, 499-502.

[10] Stamp, G., Kruzins, G. and Crowther, K. (2001) Perineal Massage in Labour and Prevention of Perineal Trauma: Randomised Controlled Trial. BMJ, 322, 1277-1280. http://dx.doi.org/10.1136/bmj.322.7297.1277

[11] El Hamid, A.A., Azzam, H.F., Ismail, G.M. and Gaafar, H.M. (2012) Effect of a Structured Antenatal Kegel Exercises Protocol on Labor Progress among Women Attending Antenatal Clinics. Egyptian Nursing Journal, 3, 2090-2106.

[12] Durmaz, A. and Buğdaycı, R. (2013) Epizyotomi iyileşmesini etkileyen faktörler (Factors Affecting the Healing of Episiotomy). Turkish Journal of Public Health, 11, $72-85$ (in Turkish).

[13] Gungor, I. and Yıldırım-Rathfısch, G. (2009) Doğum eyleminin ikinci ve üçüncü evresinin yönetiminde kanıta dayalı uygulamalar (Evidence Based Practices in the Second and Third Stage of Normal Labour). Hemşirelikte Araştırma Geliştirme Dergisi, 2, 56-65 (in Turkish).

[14] Berghella, V., Baxter, J.K. and Chauhan, S.P. (2008) Evidence-Based Labor and Delivery Management. American Journal of Obstetrics \& Gynecology, 199, 445-454. http://dx.doi.org/10.1016/j.ajog.2008.06.093

[15] Oberaigner, W., Leitner, H., Oberaigner, K., Marth, C., Pinzger, G., Concin, H., et al. (2013) Migrants and Obstetrics in Austria-Applying a New Questionnaire Shows Differences in Obstetric Care and Outcome. Wiener Klinische Wochenschrift, 125, 34-40. http://dx.doi.org/10.1007/s00508-012-0312-0

[16] Wan, X.H., Ding, Y., Abbaikeli, G., Abudureyimu, Z., Lin, L. and Tuerxun, M. (2013) Epidemiologic Study of the Risk Factors of the Adult Female Urinary Incontinence in Uygur of Kashi in Xinjiang. Chinese Journal of Obstetrics and Gynecology, 48, 916-919.

[17] Altundağ, K., Kızılırmak, A., Kartal, B. and Baser, M. (2010) Perine travmasinin önlenmesinde perine masajinin etkisi (The Effect of Perineal Massage in Preventing Perineal Trauma during Vaginal Delivery). Anadolu Hemşirelik ve Sağlık Bilimleri Dergisi, 13, 62-65 (in Turkish).

[18] Zare, O., Pasha, H. and Faramarzi, M. (2014) Effect of Perineal Massage on the İncidence of Episiotomy and Perineal Laceration. Health, 6, 10-14. http://dx.doi.org/10.4236/health.2014.61003

[19] Ismail, S.I. and Emery, S.J. (2013) Patient Awareness and Aceptability of Antenatal Perineal Massage. Journal of Obstetrics and Gynaecology, 33, 839-843. http://dx.doi.org/10.3109/01443615.2013.828027

[20] Fahami, F., Shokoohi, Z. and Kianpour, M. (2012) The Effect of Perineal Management Techniques on Labor Complications. Iranian Journal of Nursing and Midwifery Research, 17, 52-57.

[21] Beckmann, M.M. and Stock, O.M. (2013) Antenatal Perineal Massage for Reducing Perineal Trauma. Cochrane Database of Systematic Reviews, 4, Article No. CD005123. http://dx.doi.org/10.1002/14651858.CD005123.pub3

[22] Dame, J., Neher, J. and Safranek, S. (2008) Does Antepartum Perineal Massage Reduce Intrapartum Lacerations? The Journal of Family Practice, 57, 480-481.

[23] 0Baybek, H., Oflaslı, F. and Peke, Ö. (2003) Muğla devlet hastanesinde yatan gebelerin doğum sonu egzersizler hakkındaki bilgi düzeylerinin belirlenmesi (Determination of Knowledge Level of the Pregnant Women on Postpartum Exercises) Cumhuriyet Üniversitesi Hemşirelik Yüksekokulu Dergisi, 7, 28-34 (in Turkish).

[24] Dias, L.A.R., Driusso, P., Aita, D.L.C.C., Quintana, S.M., Bø, K. and Ferreira, C.H.J. (2011) Effect of Pelvic Floor Muscle Training on Labour and Newborn Outcomes: Randomized Controlled Trial. Brazilian Journal of Physical Therapy, 15, 487-493. http://dx.doi.org/10.1590/S1413-35552011005000011

[25] Halsam, J. (2003) Pelvik Floor Muscle Exercises. Journal of Nursing Times, 99, 54-55.

[26] Lemos, A., Impieri de Souza, A., Gomes Ferreira, A.L.C., Figueiroa, J.N. and Cabral-Filho, J.E. (2008) Do Perineal Exercises during Pregnancy Prevent the Development of Urinary Incontinence? A Systematic Review. International Journal of Urology, 15, 875-880. http://dx.doi.org/10.1111/j.1442-2042.2008.02145.X

[27] Mason, L., Roe, B., Wong, H., Davies, J. and Bamber, J. (2010) The Role of Antenatal Pelvic Floor Muscle Exercises in Prevention of Postpartum Stress Incontinence: A Randomised Controlled Trial. Journal of Clinical Nursing, 19, 2777-2786. http://dx.doi.org/10.1111/j.1365-2702.2010.03297.x

[28] Park, S.H., Kang, C.B., Jang, S.Y. and Kim, B.Y. (2013) Effect of Kegel Exercise to Prevent Urinary and Fecal Incontinence in Antenatal and Postnatal Women: Systematic Review. Journal of Korean Academy of Nursing, 43, 420430. http://dx.doi.org/10.4040/jkan.2013.43.3.420

[29] Eogan, M., Daly, L. and O’Herlihy, C. (2006) The Effect of Regular Antenatal Perineal Massage on Postnatal Pain and Anal Sphincter Injury: A Prospective Observational Study. Journal of Maternal-Fetal and Neonatal Medicine, 19, 225- 
229. http://dx.doi.org/10.1080/14767050600593155

[30] Jones, L.E. and Marsden, N. (2008) The Application of Antenatal Perineal Massage: A Review of Literature to Determine İnstruction, Dosage and Technique. Journal of the Association of Chartered Physiotherapists in Women's Health, 102, 8-11.

[31] Bolandhemmat, M., Salari, P., Tafazzoli, M. and Mazlloom, S.R. (2001) The Effect of Perineal Massage during Pregnancy on the Perineal Laceration in Primiparous Women. Journal of Sabzevar School of Medical Sciences, 8, 60-70.

[32] Coonrod, D.V., Bay, R.C. and Kishi, G.Y. (2000) The Epidemiology of Labor Induction: Arizona. American Journal of Obstetrics and Gynecology, 182, 1355-1362. http://dx.doi.org/10.1067/mob.2000.106248

[33] Bodner-Adler, B., Bodner, K. and Mayerhofer, K. (2002) Perineal Massage during Pregnancy in Primiparous Women. International Journal of Gynecology and Obstetrics, 78, 51-53. http://dx.doi.org/10.1016/S0020-7292(02)00065-6

[34] Salvesen, K.A. and Mørkved, S. (2004) Randomised Controlled Trial of Pelvic Floor Muscle Training during Pregnancy. BMJ, 329, 378-380. http://dx.doi.org/10.1136/bmj.38163.724306.3A

[35] Beckmann, M.M. and Garrett, A.J. (2006) Antenatal Perineal Massage for Reducing Perineal Trauma. Cochrane Database of Systematic Reviews, 1, Article No. CD005123.23. http://dx.doi.org/10.1002/14651858.CD005123.pub2

[36] Shipman, M.K., Boniface, D.R., Tefft, M.E. and McCloghry, F. (1997) Antenatal Perineal Massage and Subsequent Perineal Outcomes: A Randomized Controlled Trial. British Journal of Obstetrics and Gynaecology, 104, 787-789. http://dx.doi.org/10.1111/j.1471-0528.1997.tb12021.x

[37] Avery, M. and Burket, B. (1996) Effect of Perineal Massage on the Incidence of Episiotomy and Perineal Laceration in a Nurse Midwifery Service. Journal of Nurse-Midwifery, 31, 128-134. http://dx.doi.org/10.1016/0091-2182(86)90148-5

[38] Keenan, P. (2000) Benefits of Massage Therapy and Use of a Doula during Labor and Childbirth. Alternative Therapies in Health And Medicine, 6, 66-74.

[39] Eskiyurt, N. and Karan, A. (2000) Üriner inkontinansta fizik tedavi ve rehabilitasyon (Uriner İncontinence in Physical Therapy and Rehabilitation). Ürojinekoloji, Atlas kitapçılık, Ankara, 139-143 (in Turkish).

[40] Labrecque, M., Eason, E. and Marcoux, S. (2000) Randomized Trial of Perineal Massage during Pregnancy: Perineal Symptoms Three Months after Deliver. American Journal of Obstetrics \& Gynecology, 182, 76-80 (in Turkish). http://dx.doi.org/10.1016/S0002-9378(00)70493-5

[41] Glazener, C.M., Abdalla, M., Stroud, P., Templeton, A., Russell, I.T. and Naji, S. (1995) Postnatal Maternal Morbidity: Extent, Causes, Prevention and Treatment. British Journal of Obstetrics and Gynecology, 102, 282-287. http://dx.doi.org/10.1111/j.1471-0528.1995.tb09132.x 